\title{
HIGH-CONCENTRATION ORGANIC WASTEWATER TREATMENT USING INCLUSIVELY IMMOBILIZED SOIL BACTERIA
}

\author{
Iwahito TAKAHASHI ${ }^{1}$, Katsumi SATO ${ }^{2}$, Tomoe KOMORIYA ${ }^{3}$, Daisuke KISHINA ${ }^{4}$, \\ and Hiroaki MORITA 5 \\ ${ }^{1}$ Member of JSCE, Professor, Dept. of Civil Eng., College of Industrial Technology, Nihon University \\ (Izumi 1-2-1, Narashino, Chiba 275-8575, Japan) \\ E-mail: takahashi.iwahito@nihon-u.ac.jp (Corresponding Author) \\ ${ }^{2}$ Member of JSCE, Associate Professor, Dept. of Civil Eng., College of Industrial Technology, Nihon University \\ (Izumi 1-2-1, Narashino, Chiba 275-8575, Japan) \\ E-mail: satou.katsumi@nihon-u.ac.jp \\ ${ }^{3}$ Associate Professor, Dept. of Sustainable Eng., College of Industrial Technology, Nihon University \\ (Izumi1-2-1, Narashino, Chiba 275-8575, Japan) \\ E-mail: komoriya.tomoe@nihon-u.ac.jp \\ ${ }^{4}$ Manager, Clean Energy Department, SymEnergy Inc. \\ (4-1-5, Nihonbashi-Muromachi Chuo-ku, Tokyo 103-0022, Japan) \\ E-mail: kishina_d@symenergy.co.jp \\ ${ }^{5}$ Member of JSCE, Professor, Dept. of Civil Eng., College of Industrial Technology, Nihon University \\ (Izumi 1-2-1, Narashino, Chiba 275-8575, Japan) \\ E-mail: morita.hiroaki@nihon-u.ac.jp
}

\begin{abstract}
Activated sludge method is a wastewater treatment technique used for removing organic matter from sewage using biological floc. It is a widely used low-cost and environmentally friendly method for sewage treatment. However, this method is not suitable for treating high-concentration wastewater since it is often necessary to perform physicochemical pretreatment, such as dilution with water, pressure floatation treatment, or chemical treatment. This study aims to biologically treat high-concentration wastewater using a suitably selected soil bacteria. The soil bacteria adopted in this study were separated and cultured from the soil collected in Okinawa Prefecture in 2012. The base sequence was then determined, and the homology search was performed by the Basic Local Alignment Search Tool of the DNA Data Base of Japan. It was found to be a soil bacterium called Agrobacterium Tumefaciens by 99\% homology. When Agrobacterium Tumefaciens was directly used to treat high-concentration wastewater, it caused sludge bulking, and its treatment capacity was low and the chemical oxygen demand value found using chemiluminescence detection of permanganate index (CODMn) was unstable. However, there was no outflow of bacteria from the inside of the inclusion when Agrobacterium Tumefaciens were inclusively immobilized by the sodium alginate-acrylamide method, which suggested that the sludge volume could be reduced. The CODMn concentration of the artificial sewage added was $1500 \mathrm{mg} / \mathrm{L}$, which was exponentially attenuated, and a high removal rate of $96 \%$ was observed 12 hours after the start of treatment. Furthermore, the allowable design value for the volumetric load is $3 \mathrm{CODMn}-\mathrm{kg} / \mathrm{m}^{3}$ per day, and thus the compactification of wastewater treatment facility should be possible. These findings have proved the significance of the treatment method proposed in this article in the field of excluded facilities for the purpose of high-concentration wastewater treatment owing to its cost reduction and downscaled treatment facility advantages.
\end{abstract}

Key Words : high-concentration wastewater, biological treatment, inclusion immobilization method, soil bacteria, sludge bulking

\section{INTRODUCTION}

There are approximately 2100 sewage treatment plants in Japan (as of the end of fiscal year 2015) and most of them are based on the activated sludge method, including the conventional activated sludge method (approximately $30 \%$ of all sewage treatment plants by number, but $64 \%$ by the volume of sewage they treat) and oxidation ditch method $(45 \%)^{1)}$. The treatment method consists of the removal of organic 
matter using aerobic microorganisms with self-purifying effect that have been developed and proved in nature for millions of years. It has the advantage of being able to optimally treat wastewater by using special control technology with low operating cost although initial investment in the facility is costly $^{2), 3)}$. It can be said that this treatment process is an environment-friendly system because the main players in this treatment process are microorganisms living in nature. However, this method is not suitable for treating high-concentration wastewater, and the biochemical oxygen demand concentration of the wastewater discharged into sewerage systems from specified facilities has to be less than $600 \mathrm{mg} / \mathrm{L}$, mandated by Standard Sewer Regulations ${ }^{4)}$.

These specified facilities are defined in Article 12-2 of the Sewerage $\mathrm{Law}^{5}$. As per Article 12-1 of the Act, it is necessary to remove obstacles caused by sewage in accordance with the standards specified by a Cabinet Order ordinance, which mandates that an exclusion facility must be established or other necessary measures must be taken.

In contrast, the Water Pollution Control $\mathrm{Law}^{6}$ ) stipulates that a specified facility is a facility discharging sludge or waste that should be less than the national minimum effluent standards of $160 \mathrm{mg} / \mathrm{L}$ (daily average of $120 \mathrm{mg} / \mathrm{L}$ ), meeting any of the following requirements:

a. Containing cadmium and other substances specified by Cabinet Order as substances that may cause damage to human health

b. Chemical oxygen demand (COD), or other water contamination that may cause damage to the living environment

The pretreatment facilities to treat the drainage of these specified facilities are roughly divided into organic wastewater treatment and inorganic wastewater treatment according to characteristics of the specified facilities. While many pretreatment methods have been developed ${ }^{7), 8), 9), ~ 10), ~ 11), ~ t h e r e ~ a r e ~}$ concerns regarding area requirements and increasing costs. Hence, there is a definite need to treat high-concentration wastewater directly.

In this study, the treatment of organic wastewater, discharged from food processing plants among Specified Facilities, has been targeted. Soil bacteria were selected, identified, and cultivated to be applied for biological treatment, which is rare in the high-concentration wastewater field. That is, we aimed to reduce the waste of water resources, to downscale facilities, and to cut costs by biological treatment of high-concentration organic wastewater that cannot flow into public sewers without being diluted with groundwater or reclaimed water to reduce its concentration, sometimes using a large-scale device. We have focused on soil bacteria because they are highly adaptable to environmental changes and suitable for high-concentration treatment as they can tolerate unfavorable conditions ${ }^{12)}{ }^{13)}$. However, most soil bacteria, including actinomycetes, are regarded as encumbrances in sewage treatment since they cause sludge bulking in reaction tanks and impair solid-liquid separation ${ }^{14), 15), 16)}$. In this study, we used the sodium alginate-acrylamide method ${ }^{17), 18), 19)}$ to inclusively immobilize the cultivated bacteria, which was then used to treat high-concentration wastewater.

The inclusive immobilization method has been attracting attention since the late 1980s from the viewpoint of utilizing biotechnology for water treatment $^{20), 21), 22), 23)}$. The inclusive immobilization method involves a risk of efflux when microorganisms with specific functions are used. The advantages are as follows:

a. The microorganisms can be maintained at a high concentration and the treatment facility can be downscaled.

b. By immobilizing specific bacteria, it is possible to treat specific substances.

c. Reduction of sludge generation can be expected.

d. Solid-liquid separation becomes easier and maintenance is reduced.

e. Resistant to changes in the external environment.

Therefore, we selected, separated, and cultured microorganisms with unique functions, such as suitability for high-concentration wastewater treatment, and examined the significance of their use by inclusive immobilization.

The target of this study is the high-concentration organic wastewater; hence nitrogen, phosphorus, or

\begin{tabular}{|c|c|}
\hline Composition & Per 1 L distilled water \\
\hline Agar & $18.0 \mathrm{~g}$ \\
\hline $\mathrm{KCl}$ & $1.71 \mathrm{~g}$ \\
\hline $\mathrm{Na}_{2} \mathrm{HPO}_{4}$ & $1.26 \mathrm{~g}$ \\
\hline $\mathrm{MgSO}_{4} \cdot 7 \mathrm{H}_{2} \mathrm{O}$ & $0.05 \mathrm{~g}$ \\
\hline $\mathrm{CaCO}_{3}$ & $0.02 \mathrm{~g}$ \\
\hline $\mathrm{FeSO}_{4} \cdot 7 \mathrm{H}_{2} \mathrm{O}$ & $0.01 \mathrm{~g}$ \\
\hline $\mathrm{Humic}$ acid & $10.0 \mathrm{~mL}$ \\
\hline Alinamine & $5.0 \mathrm{~mL}$ \\
\hline Nalidixic acid & $1.0 \mathrm{~mL}$ \\
\hline Kabicidin & $0.75 \mathrm{~mL}$ \\
\hline
\end{tabular}


oil-containing substances were not considered. These factors can be considered in future studies, but this study is focused on treating high-concentration organic wastewater.

\section{EXPERIMENTAL CONDITIONS AND METHODS}

(1) Soil bacteria and the inclusive immobilization method

a) Selection, identification, and cultivation of soil bacteria

The soil bacteria adopted in this study was selected from the soil collected in Okinawa Prefecture in 2012, and had been used by Usuba et al. previously ${ }^{24)}$. However, floraformation was possible since a long time had passed, and as the bacterium had not been identified yet, we first selected and identified it from the soil sample used in Usuba et al. The soil bacteria isolation medium shown in Table 1 was used. DNA was extracted from the isolated soil bacteria using a gene-extracting kit and 16S rDNA was amplified by PCR. The base sequence was then determined, and the homology search was performed by Basic Local Alignment Search Tool (BLAST) of the DNA Data Base of Japan. It was identified to be a soil bacterium called Agrobacterium Tumefaciens by $99 \%$ homology. This bacterium does not cause diseases in humans and animals, and has hyphae similar to actinomycetes. It was cultured in the shaking culture solution shown in Table 2.

\section{b) Inclusion immobilization method}

We adopted the sodium alginate-acrylamide method for inclusion immobilization of the soil bacteria. First, the cultured strain was put on a centrifugal separator (relative centrifugal force: $9000 \times$ $\mathrm{g}, 30 \mathrm{~min}$ ) to separate it from the liquid culture medium, and the separated strain was put in a $1 \%$ sodium alginate solution, which was dripped into $2 \%$ calcium chloride solution to inclusively immobilize the strain in a spherical shape. Then, it was immersed in the acrylamide solution (composition shown in Table 3) to coat the surface to increase the strength of the carrier. We regard this as secondary inclusion and hereinafter refer to it as inclusive bacteria. The diameter of the inclusive bacteria was determined as $3 \mathrm{~mm}$ since the penetration distance of oxygen was within $1.5 \mathrm{~mm}$ of the surface of the inclusive bacteria, as proved by the DO profile measurement inside the carrier using microelectrode ${ }^{25)}$ (Fig. 1).

(2) Method employed in comparative experiment on the treatment effect with and without inclusive immobilization

In this experiment, we compared and examined the
Table 2 Composition of shaking culture solution.

\begin{tabular}{|c|c|}
\hline Composition & Per $\mathbf{1}$ L distilled water \\
\hline Glucose & $10 \mathrm{~g}$ \\
\hline Peptone & $3.0 \mathrm{~g}$ \\
\hline Yeast extract & $3.0 \mathrm{~g}$ \\
\hline $\mathrm{NaCl}$ & $3.0 \mathrm{~g}$ \\
\hline
\end{tabular}

Table 3 Composition of acrylamide solution.

\begin{tabular}{|c|c|}
\hline Composition & $\begin{array}{c}\text { Per 1 L distilled } \\
\text { water }\end{array}$ \\
\hline Acrylamide & $400 \mathrm{~g}$ \\
\hline Methylenebisacrylamide & $4.0 \mathrm{~g}$ \\
\hline 3-Dimethylaminopropionitrile & $5.0 \mathrm{~g}$ \\
\hline
\end{tabular}

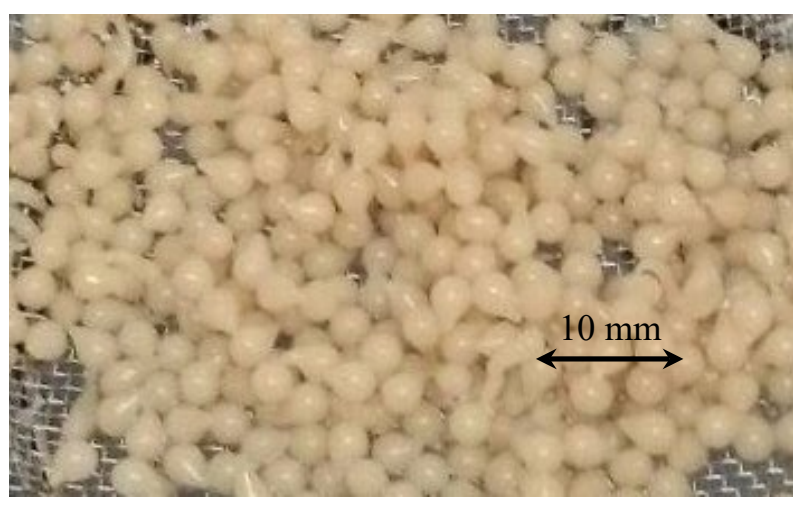

Fig. 1 Inclusive bacteria.

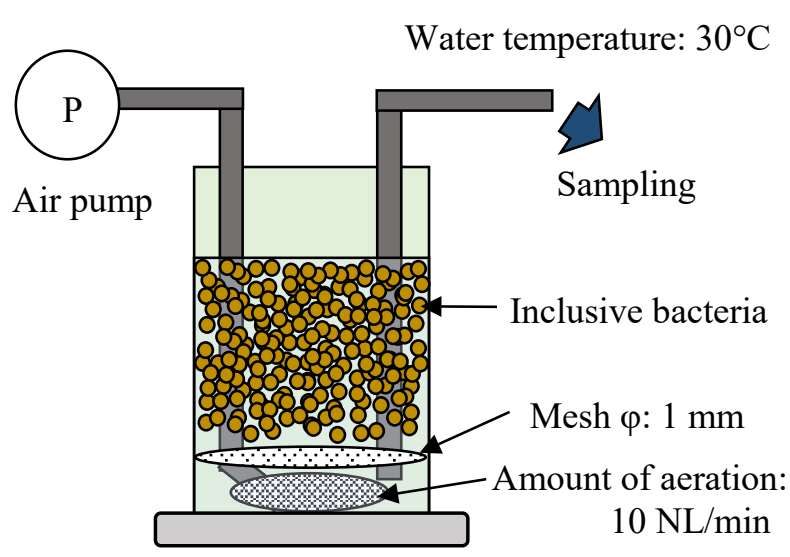

Fig. 2 Experimental apparatus. 
effects of the cultivated Agrobacterium Tumefaciens to treat high-concentration wastewater with or without inclusion to confirm the significance of inclusive immobilization. It was a continuous treatment experiment in which wastewater was changed once every 24 hours.

Figure 2 shows a schematic diagram of the experimental equipment.

The experimental method is such that $400 \mathrm{~mL}$ of artificial sewage was put into two separate containers, one with the inclusive bacteria and the other with non-inclusive bacteria, and the artificial sewage was changed once every 24 hours. The composition of the artificial sewage is shown in Table 4. The CODMn concentration of artificial sewage was set to 1500 $\mathrm{mg} / \mathrm{L} ; 2.5$ times of $600 \mathrm{mg} / \mathrm{L}$, water quality standard of inflow water to public sewers. It was set to 1500 $\mathrm{mg} / \mathrm{L}$ after we referred to the data of the beer manufacturing and soft drink factories that are typical examples of the food processing industry with a high organic matter load, and the COD value is $2000 \mathrm{mg} / \mathrm{L}$ $(6000 \mathrm{mg} / \mathrm{L}$ depending on wastewater locations and also on references ${ }^{26)}$ ) for beer and $300-600 \mathrm{mg} / \mathrm{L}$ for soft drink.

The nutrient salts in Table 4 are the solutions shown in Table 5, each of which is dissolved in 100 $\mathrm{mL}$ of distilled water, and each solution of $\mathrm{A}$ to $\mathrm{D}$ is placed in a $2 \mathrm{~mL}$ flask and further diluted to 1000 $\mathrm{mL}$.

The water temperature was set to $30^{\circ} \mathrm{C}$, the optimum temperature for the bacteria. The container was placed in a constant temperature bath to control the water temperature during the experiment. Aeration was always performed at $10 \mathrm{NL} / \mathrm{min}$ as Agrobacterium Tumefaciens are aerobic bacteria. Mixed liquor-suspended solids (MLSS) were $2500 \mathrm{mg} / \mathrm{L}$ for both test specimen. It is calculated only by the amount of contained cells, excluding the entrapment part that is not related to the actual treatment, in order to clarify the treatment effect with the amount of contained bacterial cells. The organic matter concentration was measured using CODMn by the permanganate method to immediately grasp the results, and the measurement was performed at the timing of replacement of artificial sewage.

\section{(3) Comparative experiment of treatment effect of inclusive bacteria and activated sludge}

In this experiment, we compared and examined the effect of treating the inclusive bacteria and activated sludge on high-concentration wastewater to confirm the usefulness of the inclusive bacteria. As the treatment effect was confirmed within 24 hours, the experiment was conducted in a 24-hour batch experiment. The optimum treatment time was also examined by observing the changes in concentration.
Table 4 Composition of artificial sewage.

\begin{tabular}{|c|c|}
\hline Composition & Per 1 L distilled water \\
\hline Glucose & $1.97 \mathrm{~g}$ \\
\hline Ammonium acetate & $1.68 \mathrm{~g}$ \\
\hline Polypeptone & $0.83 \mathrm{~g}$ \\
\hline Nutritive salts & $1.25 \mathrm{~mL}$ \\
\hline
\end{tabular}

Table 5 Nutritive salts.

\begin{tabular}{|c|c|c|}
\hline \multirow{2}{*}{ Solution } & Composition & $\begin{array}{c}\text { Per 100 L distilled } \\
\text { water }\end{array}$ \\
\hline \multirow{3}{*}{$\mathrm{*}$} & $\mathrm{K}_{2} \mathrm{HPO}_{4}$ & $0.175 \mathrm{~g}$ \\
\cline { 2 - 3 } & $\mathrm{KH}_{2} \mathrm{PO}_{4}$ & $0.850 \mathrm{~g}$ \\
\cline { 2 - 3 } & $\mathrm{Na}_{2} \mathrm{HPO}_{4}$ & $4.460 \mathrm{~g}$ \\
\cline { 2 - 3 } & $\mathrm{NH}_{4} \mathrm{Cl}$ & $0.170 \mathrm{~g}$ \\
\hline $\mathrm{B}$ & $\mathrm{MgSO}_{4}$ & $2.250 \mathrm{~g}$ \\
\hline $\mathrm{C}$ & $\mathrm{CaCl}_{2}$ & $2.750 \mathrm{~g}$ \\
\hline $\mathrm{D}$ & $\mathrm{FeCl}_{3}$ & $0.025 \mathrm{~g}$ \\
\hline
\end{tabular}

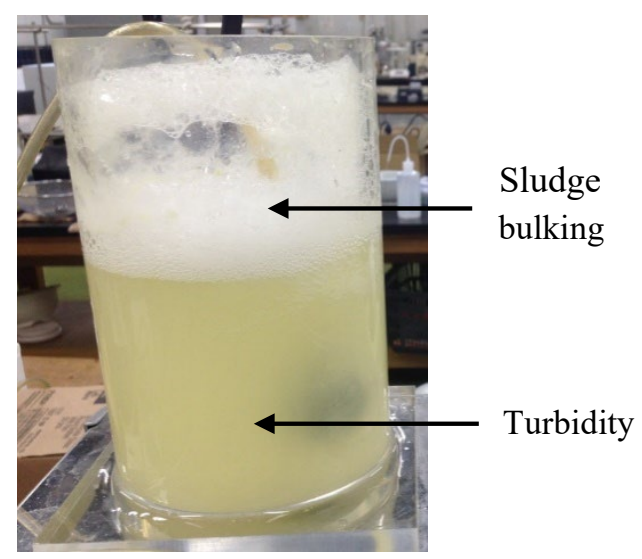

(a) Non-inclusive bacteria

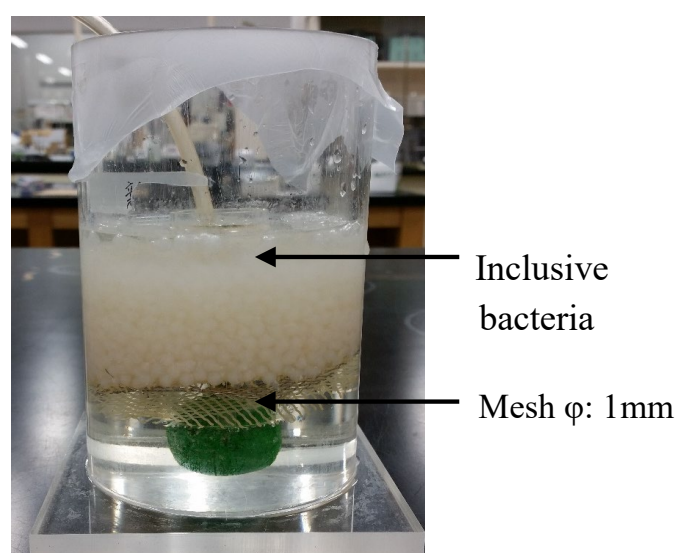

(b) Inclusive bacteria

Fig. 3 Visual observation 24 hours after launch of the experiment. 
Artificial sewage $(500 \mathrm{~mL}, \mathrm{CODMn}$ concentration $1500 \mathrm{mg} / \mathrm{L}$ ) was put in two separate containers, one with the inclusive bacteria and the other with the activated sludge, and batch process was carried out for 24 hours. Experimental conditions, such as water temperature and aeration were the same as those in the earlier experiment. MLSS was $2500 \mathrm{mg} / \mathrm{L}$ for both. The calculation was based only on the amount of contained bacteria, excluding the entrapment part, for the same reason as described in 2. (2). It was measured every two hours.

\section{RESULTS AND DISCUSSION}

\section{(1) Comparative experiment on the treatment effect with and without inclusive immobiliza- tion}

First, visual observations were made in a beaker designed as a reaction tank. Figure 3 shows the state of treatment after 24 hours with and without inclusive immobilization.

As can be seen from the photograph, sludge bulking - foaming in the upper part of the liquid and turbidity of solution - was observed in the container with non-inclusive bacteria (Fig. 3a). The sludge volume index (SVI) was extremely high at 380 , and almost no sedimentation over time was observed, which indicated that the subsequent solid-liquid separation would not be easy. Sludge bulking is a phenomenon in which the floc expands due to unusual increase in population of filamentous bacteria, making it difficult for sludge to settle. The bacteria used in this experiment were also a kind of soil bacteria that propagate easily. In contrast, neither bulking nor turbidity was observed in the container with inclusive bacteria (Fig. 3b); the cloudy upper part of the beaker was not foam but inclusive bacteria itself and it did not leak into the solution. This suggests that the bacteria population did not change significantly due to self-digestion within the inclusion. Furthermore, inclusively immobilizing the bacteria made it easy for the treated water to separate itself (solid-liquid separation) - which is also mentioned as an advantage - and suppressed the bulking phenomenon.

Second, we made a comparative review of the effects of treatment with and without inclusion. Figure 4 shows the CODMn values measured during treatment with inclusive bacteria and with non-inclusive bacteria.

There was a substantial difference in the quality of treated sewage and the properties of the treatment with and without inclusive bacteria. First, the CODMn value of inclusive bacteria changed from 50 to $200 \mathrm{mg} / \mathrm{L}$. Since the added artificial sewage con-

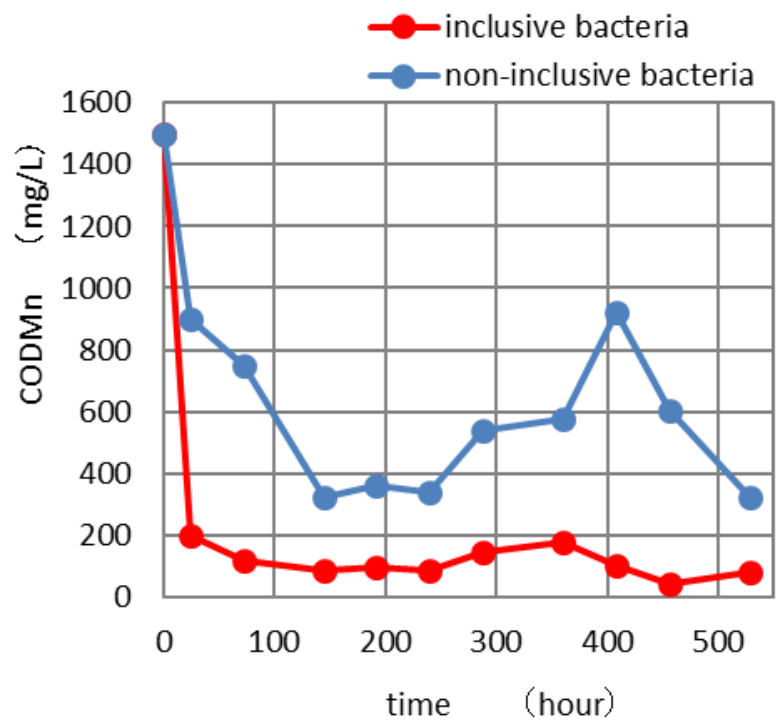

Fig. 4 Results of the treatment effect of the inclusive bacteria and non-inclusive bacteria.

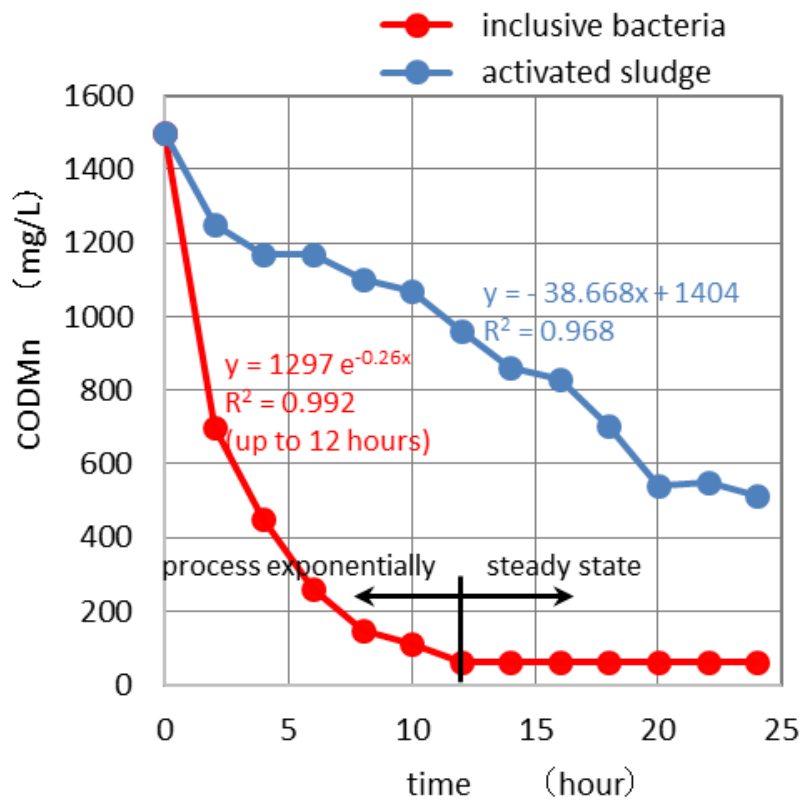

Fig. 5 Results of the treatment effect of the inclusive bacteria and activated sludge.

centration was $1500 \mathrm{mg} / \mathrm{L}$, the removal rate was always more than $90 \%$, and even more than $95 \%$ when it was higher. In contrast, the CODMn value of the solution with non-inclusive bacteria decreased to around $300 \mathrm{mg} / \mathrm{L} 140 \mathrm{~h}$ after the start of the experiment although the treatment effect in the initial stage was somewhat recognized. Subsequently, the CODMn value increased again and exceeded 900 $\mathrm{mg} / \mathrm{L}$ after $400 \mathrm{~h}$ due to the effect of the bulking phenomenon. This increase in CODMn caused a temporary increase in food intake, confirming the decrease in the CODMn value, which indicated the 
activation of the bacteria. The CODMn value of the non-inclusive bacteria repeatedly increased and decreased; the effect was not stable and the removal effect was low.

The results above show that the inclusive immobilization of Agrobacterium Tumefaciens suppressed the bulking phenomenon and had high treatment effect in high-concentration wastewater treatment. Furthermore, the amount of sludge during treatment was reduced, confirming the significance of the method used in this experiment.

\section{(2) Comparative experiment of the treatment effect of inclusive bacteria and activated sludge}

Figure 5 shows the CODMn measurement results of the 24-hour-batch experiment with inclusive bacteria and with activated sludge. The inclusive bacteria rapidly decreased to around $700 \mathrm{mg} / \mathrm{L}$ two hours after the start of the experiment, then gradually decreased and remained a steady state at $60 \mathrm{mg} / \mathrm{L}$ after 12 hours. On the other hand, the amount of activated sludge gradually decreased immediately after the start of the experiment, and did not fall below 960 $\mathrm{mg} / \mathrm{L} 12$ hours later and $500 \mathrm{mg} / \mathrm{L}$ even 24 hours later. Moreover, there was a 2.7 times difference in the removal rate 12 hours later when the CODMn of inclusive bacteria reached a steady state: $96 \%$ for inclusive bacteria and $36 \%$ for activated sludge.

Each result was subjected to regression analysis and shown on the figure with time being $\mathrm{x}$ and CODMn y. For inclusive bacteria, the results up to 12 hours from the start of the experiment were obtained, since the CODMn of inclusive bacteria became stable at $60 \mathrm{mg} / \mathrm{L}$ after 12 hours, by logarithmic approximation due to the shape of the figure. The results up to 24 hours were obtained by linear approximation for activated sludge.

The relationship between time and CODMn of inclusive bacteria is expressed by formula (1).

$$
y=1297 e^{-0.26 x}
$$

The coefficient of determination $\mathrm{R}^{2}$ was as high as 0.992, which indicated that inclusive bacteria were exponentially attenuated within 12 hours from the start of the experiment. It reached a steady state of 60 $\mathrm{mg} / \mathrm{L}$ after 12 hours. From these results, it can be said that the treatment capacity of the inclusive bacteria is limited to $60 \mathrm{mg} / \mathrm{L}$, and the optimum treatment time is 12 hours (eight hours considering only satisfying the uniform drainage standard) under the conditions of this experiment.

In contrast, the relationship between time and CODMn of activated sludge can be expressed by formula (2).

$$
y=-38.668 x+1404
$$

The coefficient of determination $\mathrm{R}^{2}$ was as high as 0.968, which indicated that the activated sludge was decaying linearly. After 20 hours, it became a steady state reaching about $550 \mathrm{mg} / \mathrm{L}$, and could not fall below the uniform drainage standard within $24 \mathrm{~h}$.

Although it cannot be simply compared because it is measured by CODMn in this experiment, the BOD volume load is 0.3 to $0.8 \mathrm{BOD}-\mathrm{kg} / \mathrm{m}^{3}$ per day in the case of the standard activated sludge method; whereas $3 \mathrm{CODMn}-\mathrm{kg} / \mathrm{m}^{3}$ per day, which normally deteriorates the treated water quality, is the allowable design value for the inclusive bacteria, and this contributes to the compactness of the wastewater treatment facility, the advantage of inclusive immobilization mentioned in the Introduction.

These results confirmed the high treatment effect and stable quality of treated wastewater of inclusively immobilized soil bacteria, such as Agrobacterium Tumefaciens, in treating high concentration wastewater (CODMn concentration $1500 \mathrm{mg} / \mathrm{L}$ ) which is difficult for activated sludge to process.

\section{CONCLUSIONS}

In this study, Agrobacterium Tumefaciens isolated and cultured from soil bacteria collected in Okinawa Prefecture was comprehensively immobilized and used to treat high-concentration wastewater with a CODMn concentration of $1500 \mathrm{mg} / \mathrm{L}$.

As a result, there was no outflow of bacteria from the inside of the inclusion, which suggested that the sludge volume could be reduced. In addition, the inclusion made it easy to separate solid and liquid, which led to reduced cost and downscaled facility area related to sludge treatment, which are heavy burdens in the operation of excluded facilities.

The high treatment effect of the inclusive bacteria was confirmed by the experimental result where the CODMn concentration of the artificial sewage was $1500 \mathrm{mg} / \mathrm{L}$, which was exponentially attenuated by the inclusive bacteria, and reached a steady state at $60 \mathrm{mg} / \mathrm{L}$ CODMn concentration and a removal rate of $96 \% 12$ hours after the start of treatment. Furthermore, the allowable design value for the volumetric load is 3 CODMn $-\mathrm{kg} / \mathrm{m}^{3}$ per day, which can be said to contribute to the compactification of wastewater treatment facilities.

These findings have proved the significance of the treatment method proposed in this article in the field of excluded facilities for the purpose of high-concentration wastewater treatment because of its cost reduction and downscaled facility area advantages. 
ACKNOWLEDGMENTS: We gratefully acknowledge the work of past and present members of our laboratory at the College of Industrial Technology, Nihon University.

\section{REFERENCES}

1) Japan Sewage Words Association: Annual Report on Sewer 2019 "Nihon-no-Gesuidō", Japan Sewage Words Association, p. 20, 2018 (in Japanese).

2) Schmidt, I., Sliekers, O., Schmid, M., Bock, E., Fuerst, J., Kuenen, J. G., Jetten, M. S. M. and Strous, M.: New concept of microbial treatment process for the nitrogen removal in wastewater, FEMS Microbiology Reviews, Vol. 27, No. 4, pp. 481-492, 2003.

3) Mudrack, K. and Kunst, S.: Biologie der Abwasser- reinigung, Springer Spektrum, pp. 57-161, 2010 (in German).

4) Ministry of Land, Infrastructure, Transport and Tourism: Standard Sewer Regulations, Koku-Sui-Ge, 53, 2015 (in Japanese).

5) Ministry of Land, Infrastructure, Transport and Tourism: Sewerage Act, No. 79 of April 24, 1958, Amendment of Act, No. 69 of 2014 (in Japanese).

6) Ministry of the Environment: Water Pollution Prevention, No. 138 of December 25, 1970, Amendment of Act, No. 47 of 2016 (in Japanese).

7) Reed, S. C., Crites, R. W. and Middlebrooks, E. J.: Natural Systems for Waste Management and Treatment, McGrawHill, pp. 433, 1998.

8) Barber, P. W. and Stuckey, C. D.: The use of the anaerobic baffled reactor (ABR) for wastewater treatment: A review, Water Res., Vol. 33, No. 7, pp. 1559-1578, 1999.

9) Nataraj, K. S., Hosamoni, M. K. and Aminabhavi, M. T.: Distillery wastewater treatment by the membrane-based nanofiltration and reverse osmosis processes, Water Res., Vol. 40, No. 12, pp. 2349-2356, 2006.

10) Gomes, R. D., Papa, G. L., Cichello, C. G., Melancon, D., Pozzi, G. E., Balieiro, C. J., Monerrey-Quintero, S. E. and Tommaso, G.: Effect of enzymatic pretreatment and increasing the organic loading rate of lipid-rich wastewater treated in a hybrid UASB reactor, Desalination, Vol. 279, No. 1-3, pp. 96-103, 2011.

11) Pattananuwat, N., Kawai, T., Hatamoto, M., Syutsubo, K., Takahashi, M., Harada, H. and Yamaguchi, T.: Development of combined anaerobic-aerobic system for treating industrial molasses wastewater, J. Water Environ. Tech., Vol. 11, No. 6, pp. 519-528, 2013.

12) El-Shatoury, S., Mitchell, J., Bahgat, M. and Dewedar, A.: Biodiversity of actinomycetes in a constructed wetland for industrial effluent treatment, Actinomycetologica, Vol. 18, No. 1, pp. 1-7, 2004.

13) Okazaki, T.: Intrigued by actinomycete diversity, Actinomycetologica, Vol. 20, No. 1, pp. 15-22, 2006.
14) Madoni, P., Davoli, D. and Gibin, G.: Survey of filamentous microorganisms from bulking and foaming activated-sludge plants in Italy, Water Res., Vol. 34, No. 6, pp. 1767-1772, 2000.

15) Juang, D.: Effects of synthetic polymer on the filamentous bacteria in activated sludge, Bioresour. Technol., Vol. 96, No. 1, pp. 31-40, 2005.

16) Li, J., Hu, B., Zheng, P., Qaisar, M. and Mei, L.: Filamentous granular sludge bulking in a laboratory scale UASB reactor, Bioresour. Technol., Vol. 99, No. 9, pp. 3431-3438, 2008.

17) Van Ginkel, C. G., Tramper, J., Luyben, K. C. A. M. and Klapwijk, A.: Characterization of Nitrosomonas europaea immobilized in calcium alginate, Enzyme Microb. Technol., Vol. 5, No. 4, pp. 297-303, 1983.

18) Tramper, J. and De Man, S. W.: Characterization of nitrobacter agilis immobilized in calcium alginate, Enzyme Microb. Technol., Vol. 8, No. 8, pp. 472-476, 1986.

19) Sumino, T., Nakamura, H. and Mori, N.: Immobilization of activated sludge by the acrylamide method, J. Ferment. Bioeng., Vol. 72, No. 2, pp. 141-143, 1991.

20) Nilsson, I. and Ohlson, S.: Columnar denitrification of water by immobilized pseudomonas denitrificans cells, Eur. J. Appl. Microbiol. Biotechnol., Vol. 14, pp. 86-90, 1982.

21) Kokufuta, E., Shimohashi, M. and Nakamura, I.: Immobilization of Paracoccus denitrificans cell with polyelectrolyte complex and denitrifying activity of the immobilized cells, J. Ferment. Technol., Vol. 64, No. 6, pp. 533-538, 1986.

22) Aravinthan, V., Takizawa, S., Fujita, K. and Komatsu, K.: Factors affecting nitrogen removal from domestic wastewater using immobilized bacteria, Water Sci. Technol., Vol. 38, No. 1, pp. 193-201, 1998.

23) Lee, Y., Lee, J., Min, Y., Hamaguchi, H. and Ghung, J.: Development of an automatic phase-contrast microscopic system capable of determining the microbial density and distribution inside an immobilized carrier, Anal. Sci., Vol. 24, No. 4, pp. 547-550, 2008.

24) Usuba, S., Takahashi, I., Kishina, D. and Ohsawa, Y.: Basic examination on inclusion immobilization method of actinomycete suitable for continuous treatment of highly-concentrated wastewater, Papers on Environmental Information Science, No. 28, pp. 227-232, 2014 (in Japanese).

25) Satoh, H., Nakamura, Y. and Ono, H.: In situ analysis of oxygen consumption in activated sludge as determined by the use of microelectrodes, J. Jpn. Soc. Water Environ., Vol. 25, No. 1, pp. 27-32, 2002 (in Japanese).

26) Simate, S. G., Cluett, J., Lyuke, E. S., Musapatika, T. E., Ndlovu, S., Walubita, F. L. and Alvarez, E. A.: The treatment of brewery wastewater for reuse: State of the art, Desalination, Vol. 273, pp. 235-247, 2011.

(Received April 8, 2020)

(Accepted March 1, 2021) 